Eur J Clin Chem Clin Biochem 1995; 33:179-194

(c) 1995 Walter de Gruyter \& Co. Berlin - New York

\title{
Markers for Vulnerability in Acute Porphyria A Hypothesis Paper ${ }^{1}$ )
} \author{
Ann Henrichson ${ }^{1}$ and Ulf Lindh ${ }^{4}$ \\ ${ }^{1}$ Porphyrias Service Sweden, Stockholm, Sweden \\ 2 Primary Health Care Centre, Arjeplog, Sweden \\ 3 Scandlab, Sollentuna, Sweden \\ ${ }^{4}$ Dept. of Radiation Sciences, University of Uppsala, Uppsala, Sweden
}

By Stig Thunell ${ }^{1}$, Christer Andersson ${ }^{2}$, Björn Carlmark ${ }^{3}, Y^{\prime}$ lva Floderus ${ }^{1}$, Sten O. Grönqvist ${ }^{4}$, Pauline Harper $^{1}$,

(Received October 6, 1994/February 2, 1995)

Summary: Previously symptomatic and permanently asymptomatic carriers of a gene mutation for acute intermittent porphyria as well as matched controls were screened with regard to a series of variables of possible relevance to the development of porphyric symptoms. The basis for the study was a concept of acute porphyria as a condition of a permanent system overload of oxidative stress, with long term effects on hepatic and renal tissue, and with instances of periodic overload of free radicals giving rise to acute neurologic involvement.

Leukocyte concentrations of manganese, calcium, iron and zinc, as well as erythrocyte calcium differed between the groups, acute intermittent porphyria gene carriers, irrespective of previous porphyric illness, showing significantly higher levels than the controls.

Manganese was found to be the most discriminative component of all the 78 variables investigated, accounting for about 98 per cent of the variance between the groups. An increment, by a factor of four, in cellular manganese is suggestive of an increase, in acute intermittent porphyria, of a manganese associated enzyme, e.g. glutamine synthetase, pyruvate carboxylase or mitochondrial superoxide dismutase. The best fit into the model considered is provided by a theory focused on superoxide dismutase, induced in response to superoxide anion radical produced from aminolaevulinic acid. In porphyria gene carriers seemingly resistent to porphyric manifestations, an increase in potentially prooxidant cellular iron is matched by a proportional increment in manganese, i. e. presumably by a corresponding mitochondrial superoxide dismutase induction. This mechanism is not operative in porphyric individuals prone to development of neuropsychiatric symptoms.

In acute intermittent porphyria with a history of porphyric illness there is a positive correlation between erythrocyte manganese and serum folate and a negative correlation between leukocyte ferrochelatase activity and serum cobalamin concentration. This may mirror a role of the cobalamin-folate system in the acute porphyric process.

1) This work was supported by grants from the Karolinska Institute.

2) Enzymes listed in the text:

Catalase (EC 1.11.1.6)

Coproporphyrinogen oxidase (EC 1.3.3.3)

Ferrochelatase (EC 4.99.1.1)

Glutamine synthetase (EC 6.3.1.2)

Glutathione peroxidase (BC 1.11.1.9)
Glyoxalase I (EC 4.4.1.5)

Porphobilinogen deaminase (EC 4.3.1.8)

Porphobilinogen synthase (aminolaevulinate dehydratase)

(EC 4.2.1.24)

Protoporphyrinogen oxidase (EC 1.3.3.4)

Superoxide dismutase (EC 1.15.1.1)

Uroporphyrinogen decarboxylase (EC 4.1.1.37) 
In the acute intermittent porphyria gene carrier state, activities of erythrocyte uroporphyrinogen decarboxylase as well as porphobilinogen deaminase are decreased. The decrease is associated with the active state of the disorder. A correlation between the activities of the two erythrocyte enzymes in non-porphyric individuals is absent in acute intermittent porphyria.

In acute intermittent porphyria with a history of porphyric illness, red cell porphobilinogen synthase (aminolaevulinate dehydratase) activity is higher than in the permanently asymptomatic cases and the controls. The increased enzyme activity is connected with recent activation of the porphyric condition.

Gene carriers of acute intermittent porphyria with a history of porphyric symptoms have a significantly higher intake of sucrose containing foodstuff. In other respects the three groups do not differ in food consumption patterns, nor in smoking or alcohol ingestion.

\section{Introduction}

The acute hepatic porphyrias comprise a group of hereditary disorders of haem metabolism. Attacks of generalized neuropathy occur in some of the porphyria gene carriers, not seldom with disablement as a result, and occasionally with fatal outcome. Since no cure for the genetic condition is yet available, the therapeutic strategy is concentrated on prophylactic measures aimed at avoiding porphyrinogenic environmental factors of notorious significance. Early recognition of the gene carrier condition is of greatest importance.

A number of hypotheses have been advanced regarding the pathogenesis of the neuropsychiatric symptoms. Focal ischaemic or necrotic cerebral lesions found at autopsy, and magnetic resonance findings of transient multifocal brain lesions similar to those seen in verified vasculopathies, have provided support for a vascular theory (1). No perceivable neuropathologic findings or observations of mild patchy neuronal losses and demyelination have favoured hypotheses focused on metabolic aberrations. These could be operating through overproduction of neuroactive compounds or substances with direct or indirect toxic effects on nerve tissue, e.g. 5aminolaevulinic acid, or through deficits in haem based factors necessary for the energy supply of the nervous system, e.g. the cytochromes of terminal oxidation (2). However, no definite explanation for the background of the neurologic disturbances in acute porphyria has yet emerged. Even less well understood is why some carriers of a porphyria gene mutation do not develop clinical manifestations in spite of even extreme exposure to porphyria precipitating agents $(3,4)$, while others are severely affected even when closely following prophylactic advice. It would be of considerable medical interest to be able to identify the porphyric individuals who are at risk for symptom development. In the present study a biochemical screening was undertaken with the hope to elucidate pathogenetic mechanisms behind the clinical manifestations in acute porphyria, and thus to find mark- ers for porphyric vulnerability. The choice of screening variables was based on the concept that overproduction of 5-aminolaevulinic acid is the key event in the metabolic process leading to neurological manifestations in porphyria. The reason was that all metabolic disturbances characterized by accumulation of 5-aminolaevulinic acid are accompanied by neurologic symptoms, i.e., tyrosinaemia, lead intoxication and the four types of acute hepatic porphyria. Also, during a porphyric attack the severity of the clinical condition is closely mirrored by the magnitude of the 5-aminolaevulinic acid accumulation, as monitored by urinary analysis (5). According to the model applied (fig. 1) the overproduction of 5aminolaevulinic acid is the result of a combination of an increased rate of formation, secondary to the induction of the enzyme generating the compound, and a decrease in its rate of further transformation, dependent on genetically determined catalytic blocks downstream of the haem synthetic pathway. The inductive process is triggered by reductions in the size of the free intracellular haem pool, the situation at hand when the production of the compound is unsufficient for the prevailing synthetic demands (5). It is known that most transition elements and heavy metals regulate haem biosynthetic and degradative activities (6-9). It may therefore be suspected that these elements are able to influence the mechanisms triggering the porphyric symptoms, and thus the phenotypic expression in porphyria. Differences in the activities of enzymes ${ }^{2}$ ) involved in haem synthesis, possibly caused by trace elements, may be another explanation for interindividual differences in porphyric morbidity. Aminolaevulinic acid does not seem to be directly neurotoxic (10), but may under certain conditions give rise to extremely toxic molecular species. Thus it has been shown that 5-aminolaevulinic acid is a potent generator of oxygen radicals and it has been proposed that it might generate in situ active oxygen species responsible for nerve binding site destruction $(11,12)$. Consequently, the free radical character of 5-aminolaevulinic acid has been implicated in the pathophysiology of acute 
porphyria (13). If the neurological involvement in porphyria should be dependent on free radical attacks on the nervous tissues, differences in the interplay between radical enhancing and protecting factors would explain the varying vulnerability evident in these disorders. Key components in this process would be the antioxidant enzymes superoxide dismutase ${ }^{2}$ ) and glutathione peroxidase $^{2}$ ) which, respectively, converts the initially generated superoxide anion radical to hydrogen peroxide, and prevents the formation of highly toxic hydroxyl radical from this compound. At higher concentrations of hydrogen peroxide, the activity of the haem-based enzyme catalase $^{2}$ ) becomes more and more important for the circumventation of the hydroxyl radical generating step of the four electron pathway for oxygen reduction (14).

Thus, gene carriers with and without a history of porphyric symptoms were compared with regard to a series of variables with possible bearing to the proposed pathogenesis of the manifestations. The main areas explored were trace element profiles, haem synthetizing enzyme catalytic activities and components signalling oxidative stress. Differences in demands for cytochrome P-450 detoxification of compounds ingested via food, alcoholic beverages or by smoking may be of significance as well, since induction of this enzyme system may drain the hepatocyte free intracellular haem pool and thus enhance the traffic through the haem synthetic pathway to the point of overload. Food consumption patterns and smoking and alcohol consumption habits were therefore included in the study. In order to unmask subclinical illness able to invalidate the matching between the groups, a series of serum and blood markers for disease were investigated as well. A total of 78 variables were compared between the two matching groups of porphyria gene carriers, and between these two groups individually and a matched control group of non-carriers.

\section{Materials and Methods}

Protocol

Carriers of a gene for acute intermittent porphyria with and without a history of porphyric symptoms, as well as matched controls, were compared with regard to a series of blood, food, alcohol consumption and smoking variables. The quantities investigated are presented in table 1 .

\section{Acute intermittent porphyria gene carriers and control} persons

Twenty presently asymptomatic gene carriers of acute intermittent porphyria, 10 with and 10 without a history of porphyric symptoms, were randomly selected from 50 previously diagnosed acute intermittent porphyria patients living in the municipality of Arjeplog in northern Sweden. Diagnosis of acute intermittent porphyria was assessed by the fact that the individual belonged to a kindred with recognized acute intermittent porphyria, and by the finding of an exon 10,198 Trp $\rightarrow$ stop mutation in the porphobili- nogen deaminase ${ }^{2}$ ) gene (15), demonstrated to be specific for the acute intermittent porphyria condition (16). Within the group of previously symptomatic acute intermittent porphyria the individuals were classified with regard to the number of porphyric attacks expericnced, to recentness of the last attack and to the severity of the symptoms. All the 10 individuals had a history of attacks of abdominal pain and increased urinary porphobilinogen excretion. Six in addition had been victims of psychiatric disturbances and 3 of neurological symptoms. None had any clinical manifestations at the time of the study. Three individuals had experienced porphyric symptoms during the month before the start of the study, three during the year preceeding the last month, and four during the four years preceeding the last year. Four of the six patients with previous acute intermittent porphyria symptoms had, during the last year, suffered from attacks one to three times. The remaining two had experienced more than four attacks. Severity of the clinical manifestion was assessed by the physician responsible for the treatment and classification of the patients. On the basis of symptomatology and magnitude of the therapeutic efforts, three individuals were estimated to have been more severely affected than the rest. In the acute intermittent porphyria gene carrier group one 74 year old woman had rheumatoid arthritis and an erythrocyte sedimentation rate of $52 \mathrm{~mm}$ (reference range $2-20 \mathrm{~mm}$ ). Six had hypertensive disease, two diabetes mellitus, one haemochromatosis and one had periods of alcohol abuse. By their own expressed opinion, and based on physical examination and laboratory tests the rest of acute intermittent porphyria gene carriers were healthy.

For each acute intermittent porphyria gene carrier one non-porphyric control was chosen matching in age, gender and geographic area. Nineteen of the 20 control persons selected took part in the study, one 65 year old woman refusing participation. Ten of the controls had hypertensive disease, two diabetes mellitus and one Bechterew's disease. Applying the same criteria as for the acute intermittent porphyria gene carrier groups, the rest of the control persons were healthy.

Mean age in the compound control group was 56 years, with a range of 25-75 years. Male/female ratio was 12/7. The corresponding figures for the acute intermittent porphyria group with a history of porphyric symptoms was 54 years, 24-74 years and 6/4, and for the asymptomatic acute intermittent porphyria group 58 years, 27-74 years and $6 / 4$, respectively.

\section{Determination of concentrations of trace elements in} blood cells and plasma

Concentrations of trace elements in erythrocytes and granulocytes were determined by the technique of positron induced X-ray emission, using the Scanning Light Ion Microscope in Uppsala, Sweden (Slim-Up). A complete description of the microscope and its performance characteristics is found elsewhere (17), as are the procedures for blood sampling, preparation of the cells from venous blood, the sample support technique and the sampling of individual cells for investigation.

Trace elements in plasma were analysed in heparinized blood by energy-dispersive X-ray fluorescence (18). Low-temperature ashing was performed prior to analysis. Atomic absorption and graphite furnace technique were used for the determinations of mercury, aluminium and cadmium in plasma.

\section{Determination of haem synthesizing enzymes}

Venous blood was collected in heparinized tubes. For analysis of erythrocyte porphobilinogen deaminase ${ }^{2}$ ) activity the blood was centrifuged for ten minutes at $1500 \mathrm{~g}\left(\mathrm{r}_{\mathrm{av}}=11 \mathrm{~cm}\right)$ and the packed red blood cells stored at $-20^{\circ} \mathrm{C}$ until assayed. Analysis of porphobilinogen synthase ${ }^{2}$ ) activity was performed on whole blood stored at $-80^{\circ} \mathrm{C}$ until assayed. For assay of erythrocyte uroporphyrinogen decarboxylase $e^{2}$ ), blood was centrifuged for 15 minutes at $4^{\circ} \mathrm{C}$ and $2000 \mathrm{~g}\left(\mathrm{r}_{\mathrm{av}}=11 \mathrm{~cm}\right)$. The red cells werc washed once with 


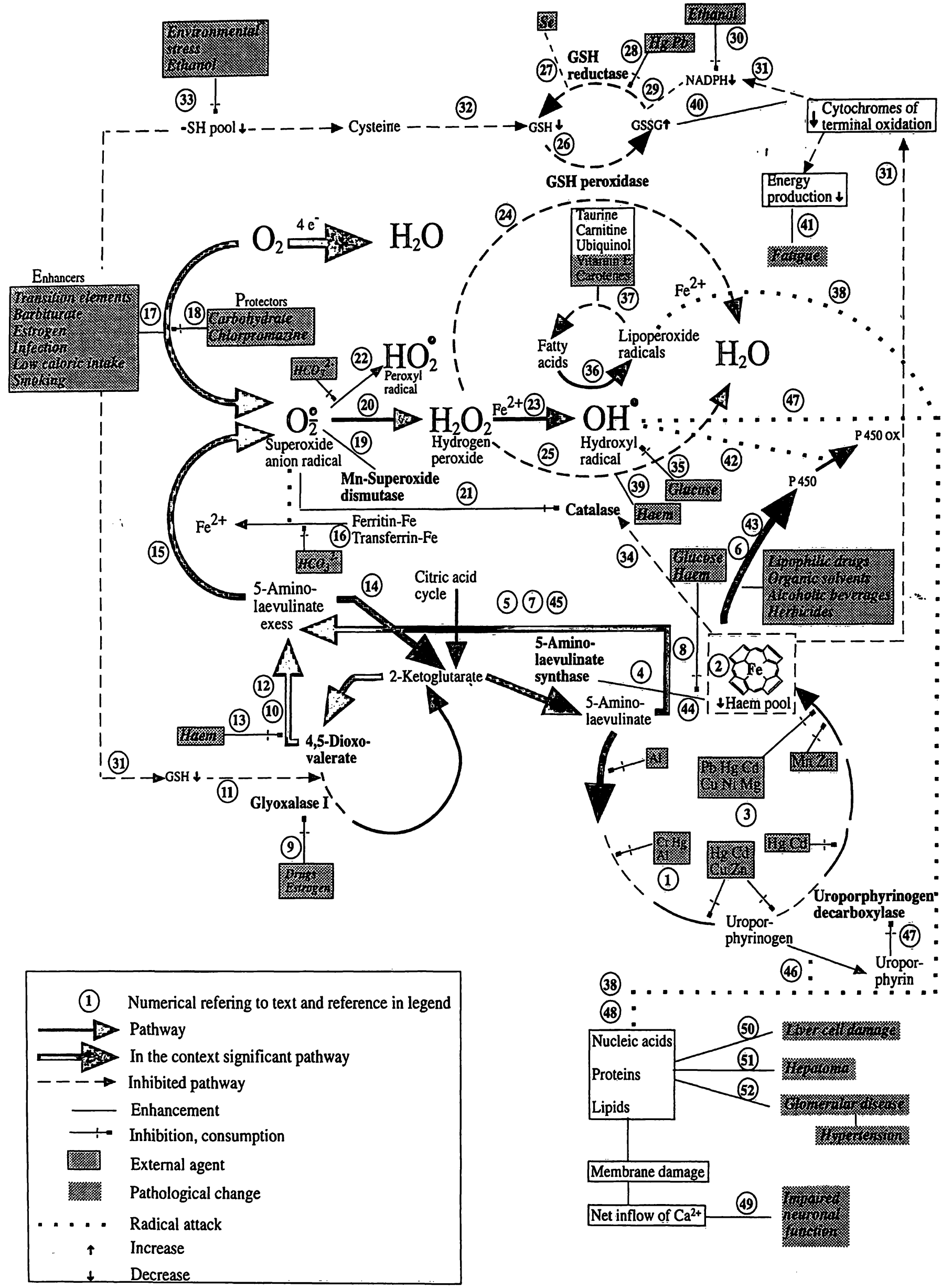


(1) In acute intermittent porphyria an needle's eye in the third step of haem synthesis

(2) causes a decrease in the intracellular free haem pool.

(3) Several metals and transition elements may add to the impairment in haem production by inhibition of enzymes in the pathway.

As a response,

(4) deinhibition of the initial enzyme in the pathway, i. c., aminolaevulinate synthase accelerates the production of 5-aminolaevulinic acid,

(5) eventually exceeding the capacity of the pathway.

(6) Xenobiotics metabolized by, and leading to, induction of cytochrome P450 cause

(7) further drain of haem, intensified 5-aminolaevulinate synthase induction and enhanced generation of 5-aminolaevulinic acid.

(8) Induction of 5-aminolaevulinate synthase is inhibited by glucose and haem.

(9) Agents inhibiting glyoxalase I, e.g. certain drugs and hormones, lead to

(10) accumulation of 4,5-dioxovaleric acid, favouring additional overproduction of 5 aminolaevulinic acid.

(11) Under conditions of diminished thiol availability, e.g. in oxidative stress, the supply of reduced glutathione is impaired and further accumulation of 4,5-dioxovaleric acid

(12) with subsequent generation of excess 5aminolaevulinic acid promoted.

(13) The enzyme catalyzing the conversion of 4,5dioxovaleric acid to 5-aminolaevulinic acid is inhibited by haem.

(14) Autooxidation of 5-aminolaevulinic acid, catalyzed by ferrous iron, gives rise to 2-oxoglutarate, recycling to 5 -aminolaevulinic acid by ways of succinate and 4,5-dioxovaleric acid, and

(15) superoxide anion radical $\left(\mathrm{O}_{2}^{-}-\right)$.

(16) Ferrous iron is fed into the process by the action of active oxygen on ferritin, and from transferrin at acidic $\mathrm{pH}$

(17) Enhancers of, and

(18) protectors against oxidative stress modify the impact of generated $\mathrm{O}_{2}$-. Also,

(19) this radical induces mitochondrial manganese superoxide dismutase.

(20) Mitochondrial and cytoplasmatic superoxide dismutases convert $\mathrm{O}_{2}^{\circ}$ - to hydrogen peroxide $\left(\mathrm{H}_{2} \mathrm{O}_{2}\right)$. Unbalanced,

(21) the superoxide anion radical inactivates catalase,

(34) thus aggravating the effects of a porphyria in duced haem deficit.

(22) Protonation of $\mathrm{O}_{2}$ - gives rise to toxic, cell membrane penetrating peroxyl radical $\left(\mathrm{HO}_{2}^{-\bullet}\right)$, a process counteracted by alkaline $\mathrm{pH}$.

(23) Hydrogen peroxide is diverted from the highly toxic hydroxyl radical pathway by

(24) the catalytic actions of glutathione peroxidase and, normally to a lesser extent,

(25) catalase, yielding $\mathrm{H}_{2} \mathrm{O}$.

(26) Glutathione peroxidase requires reduced glutathione (GSH) for its action. If the GSH pool is exhausted, e.g.
References*)

5

6-9

97

5

65

65,86

67

86

87

$11,13,41$

$11,13,41$

$53,69,88$

$52,88,89$

$53,70,88$

52,90

88

88

53

69

69

69

69
(27) because of lack of selenium (Se) for the action of glutathione reductase,

(28) because of inhibition by heavy metals

(29) because of lack of reduced nicotinamide adenine dinucleotide phosphate (NADPH) secondary to

(30) consumption on microsomal oxidation of ethanol, or

(31) dependent on a haem deficit triggered impairment of cytochromes of terminal oxidation, or

(32) because of a reduction in thiol level secondary to consumption, e.g.

(33) in environmental stress or secondary to alcohol intake.

(25) more strain is laid on the catalase pathway for $\mathrm{H}_{2} \mathrm{O}_{2}$ disposition.

(34) In a metabolic situation where catalase production is compromised, as it might be in porphyria, conditions for production of potentially toxic $\mathrm{OH}^{\bullet}$ are present.

(35) Hydroxyl radical neutralisation then depends on the efficiency of scavengers such as e.g. glucose and mannitol,

(36) and on sacrifice of fatty acids under production of lipoperoxide radicals. The efficiency of the process is a function of the fatty acid regenerative capacity of lipid soluble antioxidants, i. e.

(37) vitamin $\mathrm{E}, \beta$-carotene, ubiquinol, carnitine and taurine.

(38) Iron facilitated decomposition of surplus lipid peroxide gives rise to aldehydes and other cytotoxic products.

(39) Haem is a powerful catalyst for the conversion of $\mathrm{H}_{2} \mathrm{O}_{2}$ to $\mathrm{H}_{2} \mathrm{O}$.

During extended periods of unbalanced oxidative stress and thiol consumption, increased level of oxidized glutathione (GSSG) is a signal

(40) to divert energy from less immediate needs towards NADPH production, and

(41) the extreme prodromal fatigue of porphyria may ensue.

(42) Uncontrolled $\mathrm{OH}^{\bullet}$ promotes oxidation of cytochrome P450.

(43) Consumption of reduced cytochrome adds to the stress on the haem pool, and

(44) gives rise to further 5-aminolaevulinate synthase induction and

(45) excessive production of 5-aminolaevulinate, with increasing radical output as a result.

(46) Radical promoted oxidation of uroporphyrinogen gives rise to uroporphyrin which

(47) is an inhibitor of uroporphyrinogen decarboxylase.

(48) Free $\mathrm{OH}^{\bullet}$ radical species attack nucleic acids, proteins and lipids, altering cell membrane permeability, upsetting $\mathrm{Ca}$ homeostasis, causing intracellular $\mathrm{Ca}$ accumulation, and

(49) in the nervous system leading to neuronal dysfunction and cell death. Long standing unopposed periodical oxidative stress may cause

(50) liver cell injury,

(51) primary liver cancer, and

52. renal damage.
References*)

69

91

70

92

$12,54,55,84$ 91

85,98

$81,82,99,100$

57

*) Reports and reviews

Fig. 1 A model of porphyria as a condition of permanent system load of oxidative stress with instances of periodic overload causing clinical symptoms. 
Tab. 1 Variables investigated $*$

\begin{tabular}{|c|c|}
\hline \multicolumn{2}{|l|}{ Variablc } \\
\hline Haem synthesis & Radical metabolising enzymes \\
\hline Ervthrocyte & Blood \\
\hline $\begin{array}{l}\text { - Porphobilinogen } \\
\text { synthase } \\
\text { - inhibited activity }\end{array}$ & $\begin{array}{l}\text { - Glutathione peroxidase } \\
\text { - Superoxide dismutase }\end{array}$ \\
\hline - total activity & Trace elements \\
\hline $\begin{array}{l}\text { - Porphobilinogen } \\
\text { deaminase } \\
\text { - Uroporphyrinogen } \\
\text { decarboxylase } \\
\text { - Porphyrin }\end{array}$ & $\begin{array}{l}\text { Neutrophil leukocyte } \\
\text { - Calcium } \\
\text { - Copper } \\
\text { - Iron } \\
\text { - Magnesium }\end{array}$ \\
\hline Leukocyte & - Manganese \\
\hline - Coproporphyrinogen & $\begin{array}{l}\text { - Mercury } \\
\text { - Lead }\end{array}$ \\
\hline $\begin{array}{l}\text { - Protoporphyrinogen } \\
\text { oxidase }\end{array}$ & - Zinc \\
\hline - Ferrochelatase & $\begin{array}{l}\text { - Calcium } \\
\text { - Copper }\end{array}$ \\
\hline Serum variables & $\begin{array}{l}\text { - Iron } \\
\text { - Magnesium }\end{array}$ \\
\hline Serum & - Manganese \\
\hline - Alanine aminótransferase & - Mercury \\
\hline - Albumin & - Lead \\
\hline - Amylase & - Zinc \\
\hline - Aspartate aminotransferase & Plasma \\
\hline $\begin{array}{l}\text { - Bilinubin } \\
\text { - Calcium }\end{array}$ & - Aluminium \\
\hline - Chloride & - Cadmium \\
\hline - Cholesterol & - Copper \\
\hline - Cobalamin & - Iron \\
\hline - C-reactive protein & - Lead \\
\hline - Creatinine & - Magnesium \\
\hline - Creatine kinase & - Manganese \\
\hline - Ferritin & - Mercury \\
\hline - Folate & - Selenium \\
\hline - Glutamyl transpeptidase & - Zinc \\
\hline $\begin{array}{l}\text { - Lactate dehydrogenase } \\
\text { - Phosphate }\end{array}$ & Food consumption, smoking \\
\hline - Potassium & Bread \\
\hline - Sodium & Butter \\
\hline - Thyroxine & Cereals \\
\hline - Triiodothyronine, free & Cheese \\
\hline - Thyrotropin & Coffee, tea \\
\hline - Uric acid & Fish, salt water \\
\hline - Urea & Fruit \\
\hline & $\begin{array}{l}\text { Garlic } \\
\text { Greens }\end{array}$ \\
\hline Haematology & Intestines \\
\hline Blood & Marmalade and jam \\
\hline - Haemoglobin & Meat, domestic \\
\hline $\begin{array}{l}\text { - Erythrocyte volume } \\
\text { fraction }\end{array}$ & $\begin{array}{l}\text { Meat, game } \\
\text { Root vegetables }\end{array}$ \\
\hline $\begin{array}{l}\text { - Erythrocyte sedimentation } \\
\text { rate }\end{array}$ & $\begin{array}{l}\text { Alcohol } \\
\text { Smoking }\end{array}$ \\
\hline
\end{tabular}

ice-cold saline, again centrifuged as described above and stored at $-80^{\circ} \mathrm{C}$ until analysis. Lymphocyte pellets for coproporphyrinogen oxidase $^{2}$ ), protoporphyrinogen oxidase ${ }^{2}$ ) and ferrochelatase ${ }^{2}$ ) analysis were prepared immediately after blood collection. The cells were isolated by density gradient centrifugation with FicollPaque (Pharmacia LKB, Uppsala, Sweden), and the pellets stored at $-80^{\circ} \mathrm{C}$ until assayed. Analysis of erythrocyte porphobilinogen deaminase activity was made according to Magnussen et al. (19).
Ferrochelatase activity was determined as described by Nunn et al. (20). The rest of the enzyme ${ }^{2}$ ) assays performed represented modifications: porphobilinogen synthase $(21,22)$, uroporphyrinogen decarboxylase $(23-25)$, coproporphyrinogen oxidase $(26,27)$, protoporphyrinogen oxidase $(28-30)$. To avoid inter-assay variation each enzyme assay was performed in batch, including samples from all individuals.

\section{Determination of serum variables}

After overnight fast, venous blood was collected in tubes without anticoagulant addition. Analyses of serum alanine aminotransferase, albumin, amylase, aspartate aminotransferase, bilirubin, calcium, chloride, cholesterol, C-reactive protein, creatinine, creatine kinase, glutamyl transpeptidase, lactate dehydrogenase, phosphate, potassium, sodium, uric acid and urea, were performed on the automatic analyser Hitachi 737 and by use of reagents supplied to the instrument (Boehringer Mannheim, Germany). Radioimmunological techniques were applied for the determinations of serum cobalamin and folate (DPC Solid Phase No Boil Assay, LA, USA). Serum ferritin was determined by enzyme-immunoassay (Enzymun-Test ${ }^{\circledR}$ Ferritin, Boehringer Mannheim GmbH Diagnostica). Free thyroxine and free triiodothyronine in serum were assayed by a competitive immunoassay technique (Amerlite MAB FT4 Assay and Amerlite FT3 Assay, Kodak Clinical Diagnostics LTD, Amersham, UK). Serum human thyrotropin (hTSH) was analysed by immunoluminometric assay (Berlux ${ }^{\circledR}$ hTSH, Behringwerke AG, Marburg, Germany).

\section{Haematology}

Blood haemoglobin and erythrocyte volume fraction were determined in venous EDTA-blood by use of the Sysmex NE- $8000^{\mathrm{TM}}$ Automated Hematology Analyzer (TOA Medical Electronics CO, LTD, Kobe, Japan). Erythrocyte sedimentation rate was measured applying a technique based on sedimentation of the red blood cells in the sampling tube (Becton Dickinson GmbH, Heidelberg, Germany).

\section{Analyses of glutathione peroxidase and superoxide} dismutase activities

Whole blood glutathione peroxidase ${ }^{2}$ ) and superoxide dismutase ${ }^{2}$ ) activities were determined in heparinized blood, using the respective assays described elsewhere $(31,32)$.

\section{Evaluation of food consumption patterns, smoking habits and alcohol consumption}

Food consumption patterns, alcohol consumption, and smoking habits were evaluated in an interview situation by use of a standardized questionnaire. The variables investigated are presented in table 1 .

\section{Statistical methods}

Linear discriminant analysis was performed on the whole material to elucidate possible variables that could be used to group the cases correctly (33). Equality of group covariance matrices was verified by testing. Bivariate correlations were estimated by calculating the product-moment correlation coefficients (34). One way analysis of variance was used to try whether some single variables in one group differed significantly from the other groups. This was followed by multiple range test by Duncan's method to assess exactly which groups differed (35). Comparisons between groups were made by use of the Student's $t$-test, and relationships evaluated by linear regression analysis. 


\section{Results}

When all variables investigated were included in the discriminant analysis, it showed that leukocyte manganese accounted for about 98 per cent of the variance between the groups, and a history of a high consumption of marmalade and jam for about 2 per cent. About 97 per cent of the grouped cases were correctly classified, only one individual with asymptomatic porphyria being misclassified into the symptomatic group. On exclusion of the food consumption variables the only remaining significant discriminant function was connected with leukocyte manganese. About 87 per cent of cases were correctly classified, four asymptomatic acute intermittent porphyria individuals being misclassified into the symptomatic group, and one acute intermittent porphyria gene carrier with a history of porphyric symptoms incorrectly placed in the asymptomatic group. All controls were correctly classified. When only values for blood cell trace elements were included in the linear discriminant analysis, leukocyte manganese still accounted for the only function of significance, more than 99 per cent of the variance being attributed this variable. Half of the asymptomatic cases of acute intermittent porphyria were incorrectly placed in the symptomatic group, and three of the ten acute intermittent porphyria individuals with previous symptoms referred to the asymptomatic group. All controls were correctly classified. Among the haem synthetizing enzymes erythrocyte porphobilinogen deaminase alone contributed to the variance, allowing one hundred per cent correct differentiation between gene carriers and non-carriers, but not between cases with and without a history of porphyric symptoms.

By analysis of variance, single variables differing between the groups were identified (fig. 2). Variables which differ between the two acute intermittent porphyria groups and the control group are erythrocyte porphobilinogen deaminase and uroporphyrinogen decarboxylase activities, free erythrocyte porphyrin, leukocyte manganese, iron, zinc and calcium, erythrocyte calcium and serum calcium. Red cell porphobilinogen synthase activity and serum cobalamin differ between the acute intermittent porphyria group with a history of porphyric symptoms, on one hand, and the asymptomatic acute intermittent porphyria group and the controls on the other. Also, consumption of marmalade and jam is significantly higher in the group of previously symptomatic acute intermittent porphyria as compared to the other two groups. Serum aspartate aminotransferase is higher in the group of acute intermittent porphyria individuals with a history of symptoms than in the control group. Any differences between the groups with regard to the rest of the variables are not observed.
In the group of asymptomatic acute intermittent porphyria gene carriers, as in contrast to the group with previous porphyria symptoms and the controls, leukocyte manganese and iron concentrations correlate closely (fig. 3). Correlations between erythrocyte manganese and serum folate, and between leukocyte ferrochelatase and serum cobalamin, are noted only in the acute intermittent porphyria group with a history of porphyric symptoms. In the group of controls, in contrast to the two acute intermittent porphyria groups, correlations are noted between erythrocyte porphobilinogen deaminase and uroporphyrinogen decarboxylase activities.

In the cases of the variables found to differ between the two groups of porphyrics and the non-porphyrics (fig. 2) and/or exhibiting mutual correlations in one or two of the groups (fig. 3), the dependence of age was studied for the three different groups combined and separated, respectively, and for the groups of males and females, together and separated. In no case were the variables found to be age or sex dependent (results not shown).

Within the group of acute intermittent porphyria with a history of clinical symptoms, the same variables were compared between individuals with different numbers of porphyric attacks, differing with regard to recentness of the last attack, and/or differing with respect of the severity of the clinical condition during attacks, respectively. The observations are too few to allow statistical analysis, but in most instances a more or less symmetrical overlap of values was noted. Exceptions may be erythrocyte porphobilinogen synthase and uroporphyrinogen decarboxylase activities, as seen in figure 4 (only results from the analyses of haem synthetizing enzymes are shown).

\section{Discussion}

The matching between the groups could be potentially biased by the occurrence of current non-porphyric disease. However, in the case of diabetes mellitus, and partly also hypertensive disease, the non-acute intermittent porphyria control group were shown to match the acute intermittent porphyria groups in this respect as well. Also, in only one case, i. e. leukocyte ferrochelatase versus serum cobalamin in asymptomatic acute intermittent porphyria (fig. 3), the exclusion of values from an individual with non-porphyric disease (diabetes mellitus) resulted in a change in the statistical significance from 0.52 to 0.70 . In no other case did deletion of such values affect significances between the compared groups in any conclusive way.

The three groups investigated, i.e. acute intermittent porphyria carriers without and with a history of porph- 

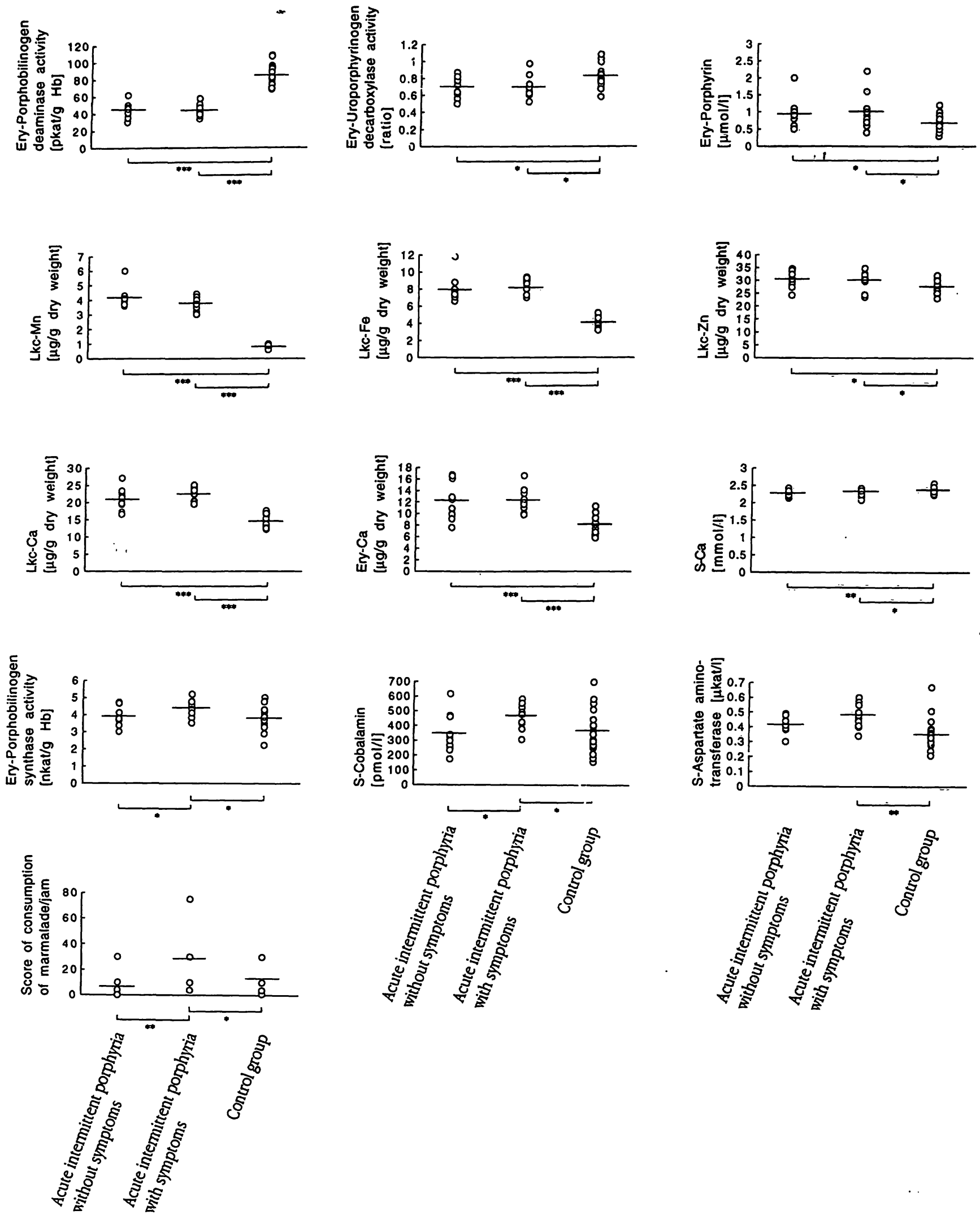

Fig. 2 Variables differing between presently asymptomatic acute intermittent porphyria individuals without, and with a history of porphyric symptoms, and a matched control group respectively.

yric symptoms, and matched controls, were not shown to differ with regard to the majority of the serum analyses or haematological quantities acting as markers for disease. The exceptions were the levels of serum aspartate aminotransferase and serum cobalamin, which were significantly higher in acute in- termittent porphyria individuals with a history of porphyric illness than in the control group (fig. 2). This finding, indicative of a subclinical hepatocyte membrane damage (36), is compatible with a concept of an 5aminolaevulinic acid-triggered oxidative attack on the liver tissue (37). 
Acute intermittent porphyria without a history of porphyric illness
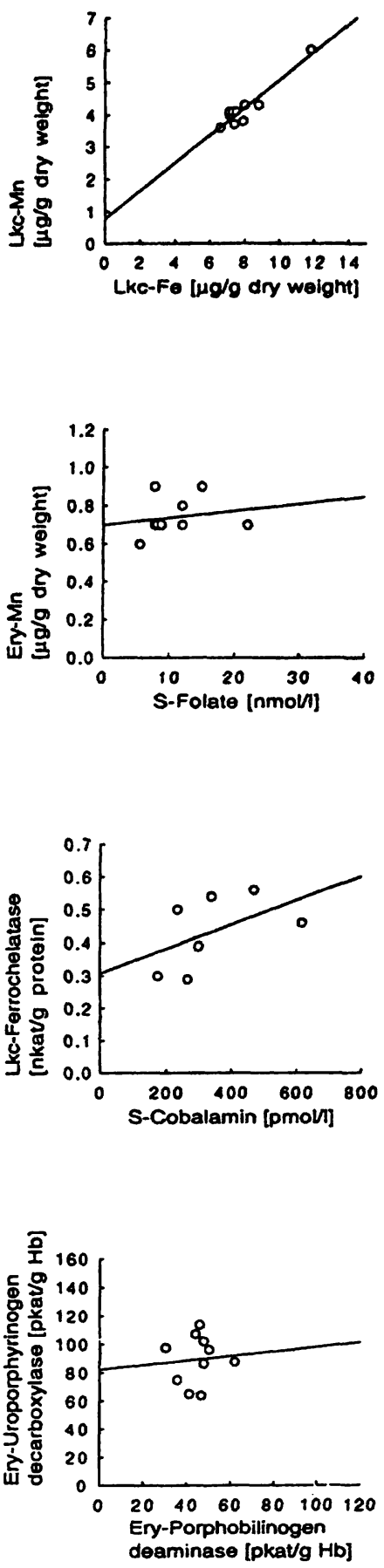

Acute intermittent porphyria with a history of porphyric illness
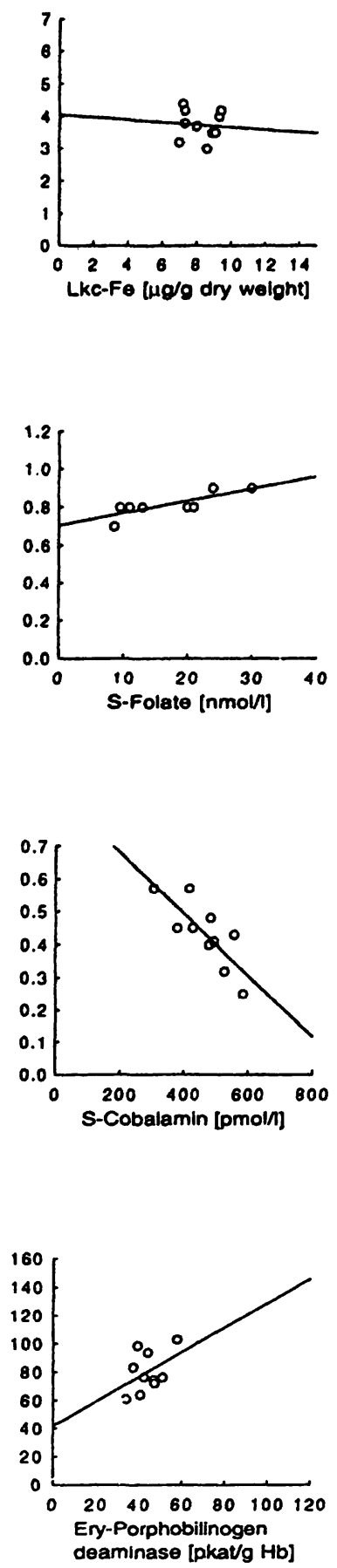

Control group
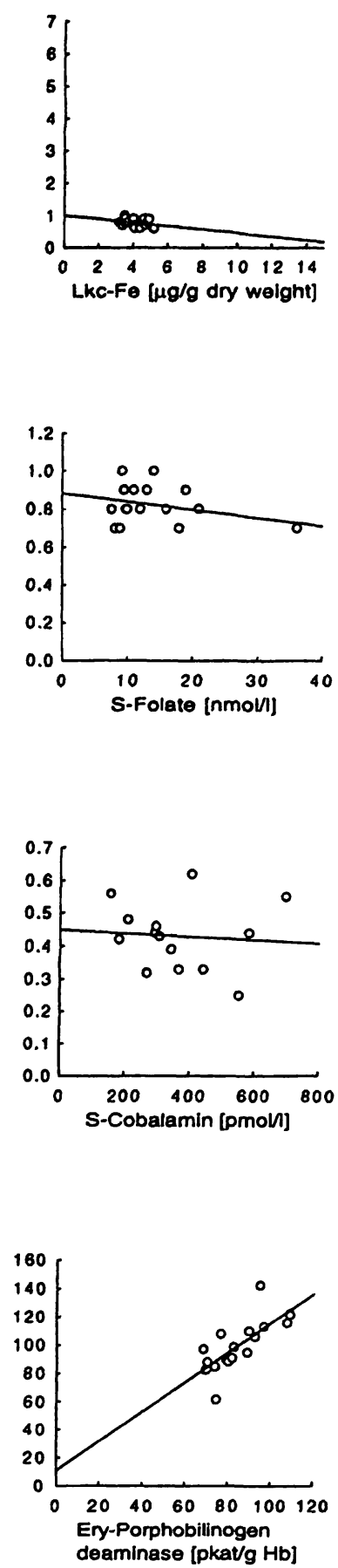

Fig. 3 Correlations between variables within the groups of acute intermittent porphyria individuals without, and with previous porphyric symptoms, and within the group of control persons:

Acute intermittent porphyria without a history of porphyric illness:

Lkc-Mn/Lkc-Fe r = 0.994, p $<0.0001$;

Ery-Mn/S-Folate $\mathrm{r}=0.183, \mathrm{NS}$;

Lkc-Ferrochelatase/S-Cobalamin $r=-0.515$, NS;

Ery-Uroporphyrinogen decarboxylase/Ery-Porphobilinogen deaminase $r=0.078$, NS.

Acute intermittent porphyria with a history of porphyric illness:

$\mathrm{Lkc}-\mathrm{Mn} / \mathrm{Lkc}-\mathrm{Fe} \mathrm{r}=-0.008, \mathrm{NS}$;

Ery-Mn/S-Folate $r=0.798, p<0.01$;
Lkc-Ferrochelatase/S-Cobalamin $r=-0.798, p<0.005$;

Ery-Uroporphyrinogen decarboxylase/Ery-Porphobilinogen deaminase $r=0.432$, NS.

Control group:

$\mathrm{Lkc}-\mathrm{Mn} / \mathrm{Lkc}-\mathrm{Fe} \mathrm{r}=0.276$, NS;

Ery-Mn/S-Folate $r=-0.292, \mathrm{NS}$;

Lkc-Ferrochelatase/S-Cobalamin $r=-0.079$, NS;

Ery-Uroporphyrinogen decarboxylase/Ery-Porphobilinogen deaminase $r=0.763, p<0.0001$

Lkc = leukocyte, Ery = erythrocyte, $S=$ serum 

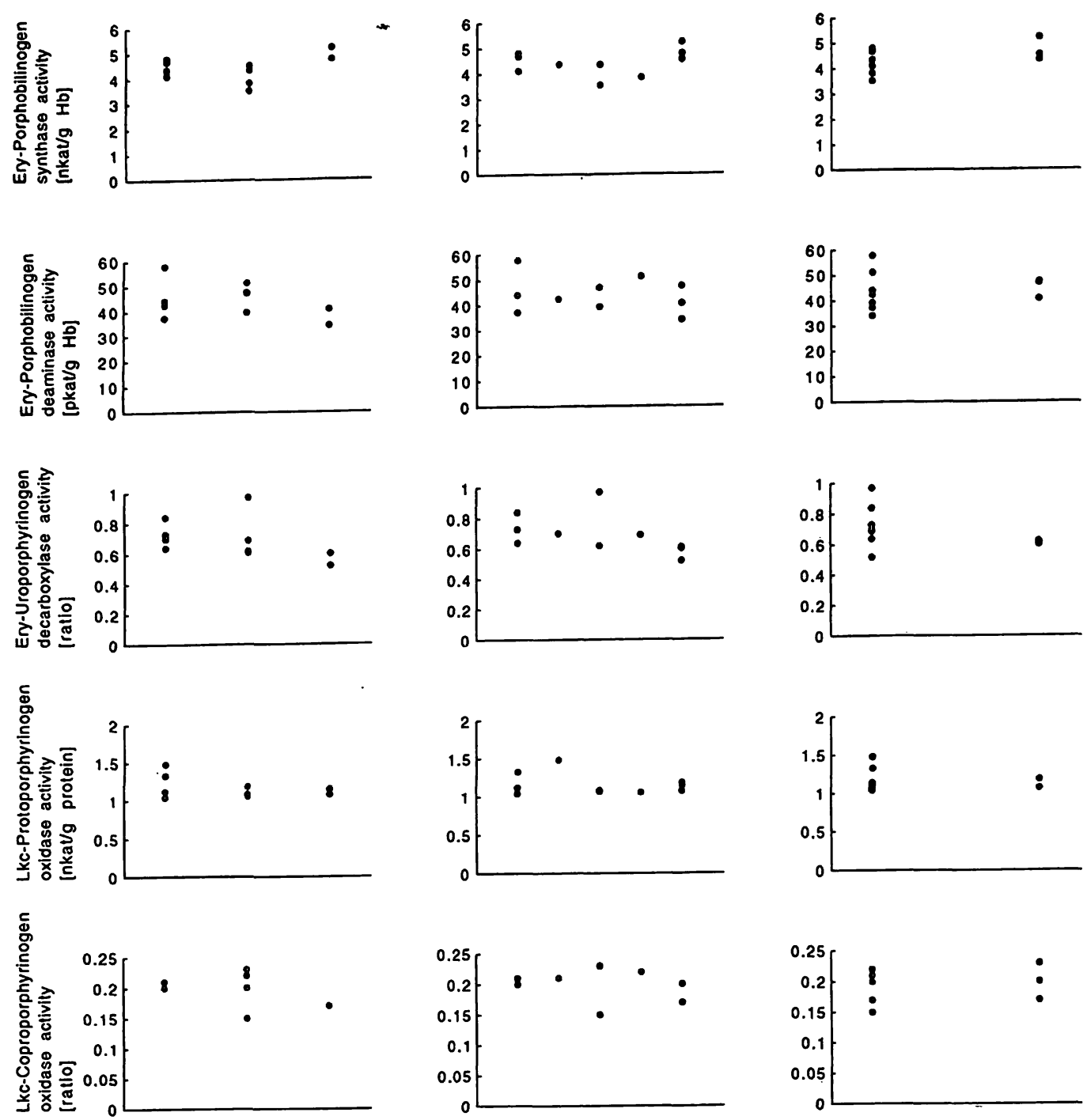

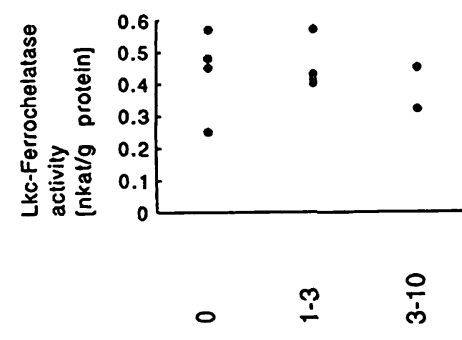

Number of attacks during the last year

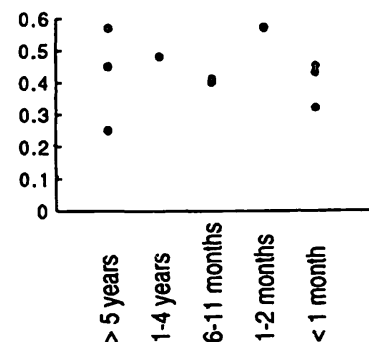

Time elapsed since the last attack

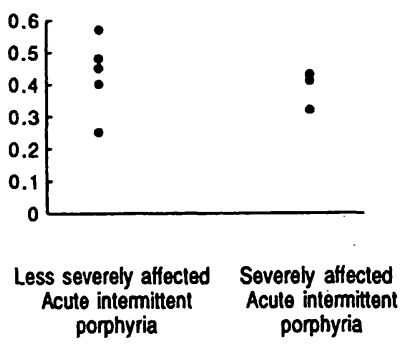

Severity of symptoms
Fig. 4 Values for erythrocyte and leukocyte activities of haem synthetizing enzymes in previously symptomatic acute intermittent

The high discriminative power of erythrocyte porphobilinogen deaminase activity as a marker for the acute intermittent porphyria gene carrier state (fig. 2) is an expected finding (38). In the present material, the diagnostic power of the analysis is exceptionally high, no overlap being found between carriers and non-carriers of acute intermittent porphyria. It is noted that gene carriers for acute intermittent porphyria with and without previous porphyric symptoms do not differ in erythrocyte porphobilinogen deaminase activity values. Differ- ing activity of the erythroid enzyme product of the nonaffected porphobilinogen deaminase allele is thus not an explanation for differences in porphyric morbidity in acute intermittent porphyria.

In the group of previously symptomatic acute intermittent porphyria individuals, but not in permanently asymptomatic acute intermittent porphyria or in controls, there is a positive correlation between erythrocyte manganese and serum folate, and a negative correlation between the ac- 
tivity of leukocyte ferrochelatase and the concentration of cobalamin in serum (fig. 3 ). It has previously been reported that folate deficiency may precipitate porphyric attacks (39) and that administration of folic acid ameliorates crises in acute porphyria (40), and the findings may be a reflection of a role of the cobalamin-folate system in the pathophysiology of acute porphyria.

In contrast to the observations in other studies (41) we did not note any increases in erythrocyte levels of antioxidant enzymes in acute intermittent porphyria. The reason may be that our assays for superoxide dismutase and glutathione peroxidase, being performed on whole blood, are not sensitive enough to register differences between normal individuals and acute intermittent porphyria gene carriers in asymptomatic phase.

In the group of previously symptomatic acute intermittent porphyria, erythrocyte porphobilinogen synthase activity is higher than in the groups of permanently asymptomatic acute intermittent porphyria and controls (fig. 2). The difference in porphobilinogen synthase activity was not found to be accompanied by any change in the size of the thiol activated fraction of the enzyme, and the activity is not correlated to any other variable investigated. However, there is a tendency for a higher activity of the enzyme in red blood cells of individuals more recently affected by clinical manifestations of acute intermittent porphyria (fig. 4), and the significantly higher porphobilinogen synthase activity in previously symptomatic individuals is mainly due to their contributions. Evidently, an attack of porphyric illness may be connected with a transitory increase in the enzyme activity of the erythrocytes, recognizable during the month following the attack and disappearing when a cohort of red cells present during the crisis fades. In view of the proposed neurotoxicity of accumulated 5-aminolaevulinic acid, it is conceivable that the increased erythrocyte porphobilinogen synthase activity is a sign of a normoblast protective mechanism operative in acute intermittent porphyria aimed at eliminating surplus 5-aminolaevulinic acid, by transformation to presumably less toxic porphobilinogen.

It has not previously been observed that erythrocyte uroporphyrinogen decarboxylase activity is decreased in acute porphyria (fig. 2), and that there is a tendency toward lower activity of this enzyme in patients with a history of more recent, more frequent and/or more severe porphyric conditions (fig. 4). As noted in figure 2, the erythrocyte porphyrin content is higher in the groups of acute intermittent porphyria gene carriers than in the control group. Since it has been shown that uroporphyrinogen decarboxylase is sensitive to an inhibitor formed on oxidation of its substrate, i. e. to uroporphyrin (42), this finding may be due to a recent oxidative action of unopposed free radicals on uroporphyrinogen (43), (fig. 1), resulting in inhibition of the decarboxylase and accumulation of porphyrin not accessible for further biotransformation.

In non-porphyric individuals there is a correlation between erythrocyte porphobilinogen deaminase and uroporphyrinogen decarboxylase activities not found in porphyrics (fig. 3). This may be a reflection of an interregulation of these two enzymes working normally, but failing at the low porphobilinogen deaminase activities in acute intermittent porphyria and during porphyric conditions of uroporphyrinogen decarboxylase inhibition. The activities of these cytoplasmatic enzymes in red blood cells should normally be determined mainly by the activities of the two pairs of alleles, one for each enzyme, that code for the active proteins, the expressions of which, conceivably, may be coupled and interregulated. At a given time the activities of porphobilinogen deaminase and uroporphyrinogen decarboxylase thus would correlate, and largely be determined by the actual size of the circulating cohort of erythrocytes with still conserved enzyme contents, i. e. younger cell elements. If one allele in one of the two pairs is silent, as is the case with the porphobilinogen deaminase producing gene in acute intermittent porphyria, a synchronised interregulation of the two enzymes would fail and changes in enzyme activities would not be proportional. In the case of partial inhibition of the active gene product of the other pair, i.e. of uroporphyrinogen decarboxylase, a gene regulated connection between the two enzyme activities would be further disturbed, resulting in correlation patterns like those observed in the present study.

Experimental, and in several cases also clinical evidence point to the fact that certain metals and transition elements as well as herbicides used in agriculture and food handling may have the capacity to precipitate illness in the inducible porphyrias (fig. 1). Consequently, individuals carrying a gene for acute hepatic porphyria are advised to avoid exposition to such agents. In the present material we have not been able to document any differences in plasma concentration of lead, mercury, cadmium, iron, copper, aluminium, zinc, magnesium, manganese or selenium which can serve as an explanation for porphyric vulnerability. Nor are any differences in alcohol consumption or smoking habits noted. The observation that individuals with previous acute intermittent porphyria symptoms consume significantly more marmalade and jam probably reflects an adaptive behaviour aimed to benefit from the prophylactic effect of the sugar component of these food-stuffs. In other respects the food consumption patterns do not differentiate between the groups studied, and can thus not explain the differences in porphyric vulnerability. 
In contrast, leukocyte levels of manganese, iron, calcium and zinc are found to be considerably higher in individuals carrying the acute intermittent porphyria gene than in non-carriers (fig. 2). They also show higher levels of erythrocyte calcium and lower concentrations of serum calcium. The values for these variables do not differ between acute intermittent porphyria individuals with and without a history of porphyric symptoms. Increases of leukocyte manganese, calcium and iron concentrations have been observed in inflammatory disease (44). In the present material only one person within the acute intermittent porphyria group was affected by such a condition. The rest exhibited normal values for inflammatory markers in blood. Since the study was performed in a non-symptomatic phase of acute intermittent porphyria it seems improbable that the changes should represent reactive blood cell responses to active porphyric illness.

Manganese proved to be the paramount discriminative component among the 78 variables investigated. This element is a potent modulator of a multitude of signal transduction pathways in the body (45). If the increased leukocyte contents of this element is a reflection of a generalized cellular condition, many of its documented biological effects are of potential interest in the pursuit of an explanation for the pathogenesis of porphyric illness. It seems, however, less probable that an element such as manganese should exist in cells in free form in concentrations as high as those noted in porphyria, without resulting in cell damage. More likely it is bound to proteins with specific functions, and the activity of any of the manganese associated enzymes glutamine synthetase, pyruvate carboxylase and mitochondrial superoxide dismutase (46-48) may be of functional relevance in the porphyric condition.

Eighty per cent of the manganese in the brain is associated with glutamine synthetase (49). This enzyme catalyses the formation of glutamine from the fast acting somatosensory transmitter glutamate (50). It is interesting to note that the substrate for glutamine synthetase is the immediate precursor of the neuroactive 5-aminolaevulinic acid analogue $\gamma$-amino butyric acid, and that an increased activity of the enzyme thus will also affect the availability of this neurotransmitter.

The product of the pyruvate carboxylase reaction is oxaloacetate. This compound is both a stoichiometric intermediate in gluconeogenesis and a catalytic intermediate in the citric acid cycle (51). The fate of oxaloacetate depends on the energy state of the cell. In an ATP deficient situation a large output of oxaloacetate will give rise to a potentially porphyrinogenic situation by being channelled into the citric acid cycle, thus adding to the pool of the porphyrinogen precursor succinyl-CoA. An overexpression of the enzyme, or induction secondary to a deficient energy production, will thus add to the strain on the weak porphobilinogen deaminase step in acute porphyria. This would explain the phenomenon that porphyric individuals in several cases develop neuropsychiatric manifestations on porphobilinogen deaminase enzyme levels which in non-carriers of a porphyric gene are not associated with porphyric symptomatology. It also gives a further rationale for the therapeutic use of glucose in acute porphyric crises.

The best fit into the pathogenetic model tested is provided by the manganese based mitochondrial superoxide dismutase. This metalloenzyme is induced under conditions associated with production of superoxide anion (52). In view of the findings in inflammatory disease it is conceivable that the high granulocyte manganese contents in porphyria is a reflection of such an induction secondary to oxidative stress (fig. 1). The increased cellular contents of iron in acute intermittent porphyria gene carriers observed in the present study (tab. 2), is of considerable interest in this context, since the ferrous form of this element participates in the generation of oxygen radicals from 5-aminolaevulinic acid, and also plays a central role in the superoxide-driven Fenton's chemistry (53) which generates toxic hydroxyl radicals (fig. 1). Further, it is noteworthy that in the permanently asymptomatic acute intermittent porphyria individuals seemingly resistent to porphyric illness, increased levels of iron are matched by increments in manganese, i. e. according to the model exploited, by an induction of mitochondrial superoxide dismutase. This correlation is not present in acute intermittent porphyria individuals prone to symptom development, which may be interpreted as the abscence of an important antiporphyrinogenic, and protective, factor.

The fact that the increase in cellular manganese is also observed in currently asymptomatic acute intermittent porphyria suggests a permanent production of reactive oxygen species in the porphyria gene carrier state. An unlimited source for reactive oxygen in acute hepatic porphyria is 5-aminolaevulinic acid $(11,12,41,54)$, and it is likely that 5 -aminolaevulinic acid derived oxygen radicals are produced locally within a nervous tissue sharing the genetic porphobilinogen deaminase defect in acute intermittent porphyria. Aminolaevulinate has been shown to give rise to mitochondrial damage (37), evidently due to lipid peroxidation (55). Since nervous tissue is known to be exceptionally sensitive to free radical injury (56), a steady generation of 5-aminolaevulinate within the nerve cell would build up a potentially injurious hyperoxidative state. It has also been observed that reactive oxygen metabolites derived from blood can produce damages to extravascular tissue (57), and such increments in free radical activity yould add to the oxida- 
tive stress within the nervous system. A possible source for reactive oxygen species is tumour necrosis factor or interleukin-1 acting on susceptible cells, processes which have been observed to give rise to induction of mitochondrial superoxide dismutase $(58,59)$. At the present, however, no model is available for an interconnection of cytokines and granulocyte manganese superoxide dismutase induction in non-symptomatic acute intermittent porphyria gene carrier states.

In acute porphyria regarded as a state of augmented generation of partially reduced oxygen, local variations in the balance between pro- and antioxidants can explain the varying susceptibility to porphyric neuropathy and also determine the actual locations of the lesions within the nervous system. A continuous input of energy is needed for the channelling of reactive oxygen species into less harmful products. If energy production is impaired, as it may permanently be in a haem deficit situation resulting from a porphyric block in the pathway, this protective mechanism is weakened, especially under circumstances of caloric restriction. This may be one reason for the precipitation of porphyric attacks by fasting. Assuming the cell has sufficient components at its disposal in the radical defence system with the capacity to prevent the formation of the hydroxyl radical, or neutralize its effect, the induction of superoxide dismutase gives rise to a strong protective potential, directing hydroxyl radicals away from the cell damaging hydroperoxyl radical pathway (60), (fig. 1). On the other hand, if the activity of glutathione peroxidase is low, e.g. secondary to deficits in selenium or cysteine, or if the production of catalase is impaired, which may be the case in conditions where haem synthesis is disturbed, toxic hydroxyl radicals are produced in proportion to the degree of superoxide dismutase induction. These are neutralized by fatty acids, but if the regeneration of these molecular species is inhibited for lack of vitamin $E, \beta$ carotene and/or for the endogenously produced carnitine, taurine and ubiquinone, unopposed reactive hydroxyl radicals will eventually be generated and give rise to damage to cellular nucleic acid, protein and lipid constituents $(53,61-64)$. Differences in the supply of compounds with antioxidant action may, by these mechanisms, account for differences in porphyric morbidity.

A mechanism amplifying the porphyrinogenic action of reactive oxygen species is found in their effects on the throughput of the glyoxalase cycle. If the conversion of dioxovaleric acid is inhibited by a deficit in reduced glutathione, e.g. arising from a consumption of this substance secondary to handling of an increased load of hydrogen peroxide, or because of a haem-deficit derived impairment of oxidative metabolism (fig. 1), more of this compound will be directed into the haem synthetic pathway, and further equivalents of reactive oxygen, originating from the increased synthesis of 5-aminolaevulinic acid will be produced. The same is the case if the enzymatic conversion of dioxovaleric acid is interfered with by inhibition of glyoxalase activity by certain drugs and hormones (65).

In the model of acute porphyria as a hyperoxidative condition, the profound therapeutic effect of administered haematin (66) is explained by its inhibitory action on the conversion of dioxovaleric acid to 5-aminolaevulinic acid (67), as well as by the inhibition of aminolaevulinate synthase induction. Also, haematin is one of the most effective iron chelators for catalysis of the decomposition of hydrogen peroxide to water (53), an activity compensating for failing glutathione peroxidase and catalase activities. The porphyrinogenic properties of e.g. barbiturates and oestrogen, as well as the negative effects in porphyria of low caloric intake, smoking and infection, may be secondary to the radical enhancing effects of these external agents. Similarly, the negative effect of carbohydrate restriction and the existence of the therapeutically exploited "glucose effect" in acute porphyria (68) may be explained on basis of the protective action of glucose in oxidative stress (69). The notorious porphyrinogenic action of ethanol can be due to impairment of the glutathione peroxidase pathway for disposing of hydrogen peroxide. The reason would be found in a depletion of reduced glutathione secondary to NADPH consumption (70) and subsequent reduction of the cellular thiol pool. The latter mechanism also accounts for the attack triggering effect of environmental stress. A rationale for the, anecdotic, use of permanent bicarbonate medication in acute intermittent porphyria, is obtained by the dependency of acid $\mathrm{pH}$ of the processes liberating prooxidant catalytic ferrous iron from protein chelators. Also, the generation of highly toxic peroxyl radicals from superoxide anions is favoured by an acidic $\mathrm{pH}(53)$.

Another mechanism behind a rise in intracellular manganese, and resulting in augmented production of free radicals, would be a primary overexpression of the gene for mitochondrial superoxide dismutase (71). In the dismutation reaction the enzyme exhibits a bell-shaped protective effect against free radicals, at higher as well as lower concentrations giving way for increased lipid peroxidation $(72,73)$. The superoxide dismutase also catalyzes the formation of hydroxyl radical from hydrogen peroxide (74), and the generation of peroxynitrite from nitric oxide and superoxide which decomposes to the highly reactive hydroxyl free radical (75). These paradoxical effects of superoxide dismutase may be of significance in porphyric neuropathy, as a high expression of mutant superoxide dismutase in mice has been observed 
to cause damages to the ventral horn neurons of the spinal cord, i. e. the part of the nervous system taking the brunt of the damage in human acute porphyria $(76,77)$.

Since nitric oxide modulates the effects of free radical species (78), the selective vulnerability of neurological tissues accounting for the porphyric neuropsychiatric syndrome, may be due to variations in the expression and inducibility of the nitric oxide synthases responsible for the local generation of the gas.

The well known association between the acute porphyria gene carrier state and liver cancer $(79,80)$ is explained by a theory of permanent oxidative stress. Cancer development requires one half to two thirds of the life span of the organism, and a long standing production of partially reduced oxygen in porphyria would, if unopposed, cause DNA damages (12) and initiate neoplastic transformation $(81,82)$. Constrictive response in the glomerular microcirculation, provoked by reactive oxygen species, can be the reason for the kidney engagement $(57,83)$. Cell membrane permeability changes induced by free radicals and accompanied by entry of calcium may account for the finding of increased erythrocyte calcium in the acute intermittent porphyria gene carrier state (fig. 2). Ionized calcium derived from extracellular sources can, under certain conditions, promote a calmodulin dependent superoxide radical production (84), and in nervous tissue a loss of calcium homeostasis resulting in elevated intracellular calcium activity causes structural damage to neurons and results in cell death (85).

The observations in the present study are compatible with a theory of clinical acute intermittent porphyria as

\section{References}

1. King PH, Bragdon AC. MRI reveals multiple reversible cerebral lesions in an attack of acute intermittent porphyria. Neurology 1991; 41:1300-2.

2. Moore MR, McColl KEL, Rimington C, Goldberg A. Pathogenesis of the neuropathy of acute porphyria. In: Wintrobe MM, editor. Disorders of porphyrin metabolism. New York and London: Plenum Publishing Corporation, 1987:119-37.

3. Kauppinen R, Mustajoki P. Prognosis of acute hepatic porphyria: occurrence of acute attacks, precipitating factors and associated diseases. Medicine 1992; 71:1-13.

4. Thunell S, Floderus Y, Henrichson A, Moore MR, Meissner P, Sinclair J. Alcoholic beverages in acute porphyria. J Stud Alcohol 1992; 53:272-6.

5. Kappas A, Sassa S, Galbraith RA, Nordmann Y. The porphyrias. In: Scriver CR, Beaudet AL, Sly WS, Valle D, editors. The metabolic basis of inherited disease. New York: McGrawHill, 1989:1305-65.

6. Maines MD. New developments in the regulation of heme metabolism and their implications. In: Goldberg L, editor. Critical reviews in toxicology. Boca Raton, FL: CRC Press. 1984:241-313.

7. Farmer DJ, Hollebone BR. Comparative inhibition of hepatic hydroxymethylbilane synthase by both hard and soft metal cations. Can J Biochem Cell Biol 1984; 62:49-54. a radical powered process, secondary to a steady production of reactive oxygen species within the nervous system, and aggravated by increments in the oxidative stress level caused by temporary increases in 5-aminolaevulinic acid production and/or contributions of radicals from other sources. The localisation to nervous tissue may depend on the local balance at critical anatomical sites between enhancers and protectors for oxidative stress. The model comprises several balance points between pro- and antioxidant forces, triggering points for selfrecruiting radical generating circuits, and critical factors on which the antioxidant system is dependent of a constant supply, or which are prey to expediture by consumption. Such a labile system, fluctuating around a basal level of 5-aminolaevulinic acid-driven oxidative challenge varying in magnitude between different individuals, and within one individual at different times, would account for the unpredictable outcome of the porphyria gene carrier state, and for the sinister long term effects of the porphyric condition on hepatic and renal tissues. The findings bring up the question whether porphyric vulnerability may be due to failure of the protective interplay between mitochondrial superoxide dismutase and intracellular ferrous iron. Interpretations föcused on manganese associated enzymes other than mitochondrial superoxide dismutase, however, stand open and further studies are needed to elucidate the pathophysiological implications of the granulocyte trace element increments and enzymatic aberrations observed in the major Swedish mutation of acute intermittent porphyria.

8. Rossi E, Attwood PV, Garcia-Webb P. Inhibition of human lymphocyte coproporphyrinogen oxidase activity by metals, bilirubin and haemin. Biochim Biophys Acta 1992; 1135:262-8.

9. Beri R, Chandra R. Chemistry and biology of heme. Effect of metal salts, organometals, metalloporphyrins on heme synthesis and catabolism, with special reference to clinical implications and interactions with cytochrome P-450. Drug Metabol Rev 1993; 25:49-152.

10. Gorchein A, Webber R. $\delta$-Aminolaevulinic acid in plasma, cerebrospinal fluid, saliva and erythrocytes: studies in normal, uraemic and porphyric subjects. Clin Sci 1987; $72: 103-12$.

11. Monteiro HP, Abdalla DSP, Augusto O, Bechara EJH. Free radical generation during $\delta$-aminolevulinic acid autoxidation: induction by hemoglobin and connections with porphyrinopathies. Arch Biochem Biophys 1987; 271:206-16.

12. Onuki J, Medeiros MHG, Bechara EJH. Di Mascio P. 5Aminolaevulinic acid induces single-strand breaks in plasmid pBR322 DNA in the presence of $\mathrm{Fe}^{2+}$ ions. Biochim Biophys Acta 1994; 1225:259-63.

13. Hermes-Lima M, Pereira B, Bechara EJH. Review. Are free radicals involved in lead poisoning? Xenobiotica 1991; $21: 1085-90$. 
14. Southorn PA, Powis G. Free radicals in Medicine. I. Chemical nature and biological reactions. Mayo Clin Proc 1988; 63:381-9.

15. Lee JS, Anvret M. Identification of the most common mutation within the porphobilinogen deaminase gene in Swedish patients with acute intermittent porphyria. Proc Natl Acad Sci USA 1991; 88:10912-5.

16. Andersson C, Thunell S, Floderus Y, Forsell C, Lundin G, Anvret $\mathrm{M}$, et al. Porphobilinogen deaminase mutation analysis in the diagnosis of acute intermittent porphyria in Northern Sweden. A clinical evaluation. J Int Med. In press.

17. Sunde T, Nyström J, Lindh U. The new scanning nuclear microprobe in Uppsala. Nuclear Instruments and Methods in Physical Research 1991; B54:80-3.

18. Sky-Peck HH, Joseph BJ. Determinations of trace elements in human serum by energy-dispersive $\mathrm{X}$-ray fluorescence. Clin Biochem 1981; 14:126-31.

19. Magnussen CR, Levine JB, Doherty JM; Cheesman JO, Tschudy DP. A red cell enzyme method for the diagnosis of acute intermittent porphyria. Blood 1974; 44:857-68.

20. Nunn AVW, Norris P, Hawk JLM, Cox TM. Zinc chelatase in human lymphocytes: detection of the enzymatic defect in erythropoietic protoporphyria. Anal Biochem 1988; 174:146-50.

21. Granick JL, Sassa S, Granick S, Levere RD, Kappas A. Studies in lead poisoning II. Correlation between the ratio of activated to inactivated $\delta$-aminolevulinic acid dehydratase of whole blood and the blood lead level. Biochem Med 1973; 8:149-59.

22. Berlin A, Schaller KH. European standardized method for the determination of $\delta$-aminolevulinic acid dehydratase activity in blood. Z Klin Chem Klin Biochem 1974; 12:389-90.

23. De Verneuil H, Nordmann Y, Phung N, Grandchamp B, Aitken G, Grelier M, et al. Familial and sporadic porphyria cutanea tarda: two different diseases. Int $\mathrm{J}$ Biochem 1978; 9:927-31

24. Elder GH, Wyvill PC. Measurement of uroporphyrinogen decarboxylase using porphyrinogens prepared by chemical reduction. Enzyme 1982; 28:186-95.

25. De Verneuil H, Sassa S, Kappas A. Purification and properties of uroporphyrinogen decarboxylase from human erythrocytes. A single enzyme catalyzing the four successive decarboxylations of uroporphyrinogen I and III. J Biol Chem 1983; 258:2454-60.

26. Li F, Lim CK, Peters TJ. A high-performance-liquid-chromatographic method for the assay of coproporphyrinogen oxidase activity in rat liver. Biochem J 1986; 239:481-4.

27. Guo R, Lim CK, Peters TJ. Accurate and specific HPLC assay of coproporphyrinogen III oxidase activity in human peripheral leukocytes. Clin Chim Acta 1988; 177:345-52.

28. Brenner DA, Bloomer JR. A fluorometric assay for measurement of protoporphyrinogen oxidase activity in mammalian tissue. Clin Chim Acta 1980; 100:259-66.

29. Deybach JC, De Verneuil H, Nordmann Y. The inherited enzymatic defect in porphyria variegata. Hum Genet 1981; $58: 425-8$

30. Jacobs NJ, Jacobs JM. Assay for enzymatic protoporphyrinogen oxidation, a late step in heme synthesis. Enzyme 1982; 28:206-19.

31. Paglia DE, Valentine WN. Studies on the quantitative and qualitative characterization of erythrocyte glutathione peroxidase. J Lab Clin Med 1967; 60:158-69.

32. Crapo JD, McCord JM, Fridovich I. Preparation and assay of superoxide dismutase. In: Bergmeyer HU, editor. Methods in enzymology, Mühlheim, Bergstraße, 1978:382-93.

33. McLachlan GJ. Discriminant analysis and statistical pattern recongnition. New York: John Wiley \& Sons, Inc, 1992.

34. Johnsson RA, Wichern DW. Applied multivariate statistical analysis. New Jersey: Prentice-Hall, 1982.

35. Box GEP, Hunter WG, Hunter JS. Statistics for experimenters. New York: Wiley, 1987.
36. Biempica L, Kosower N, Ma MH, Goldfischer S. Hepatic porphyrias. Cytochemical and ultrastructural studies of liver in acute intermittent porphyria and porphyria cutanea tarda. Arch Pathol 1974; 98:336-43.

37. Pereira B, Curi E, Kokubun E, Bechara EJH. ALA plays a prooxidative role in vivo with liver mitochondrial damage. $J$ Appl Physiol 1992; 72:226-30.

38. Strand LJ, Meyer UA, Felsher BF, Redeker AG, Marver HS. Decreased red cell uroporphyrinogen I synthetase activity in acute intermittent porphyria. J Clin Invest 1972; 51:2530-6.

39. DiMario FJ, Quinn JJ, Zalneraitis EL, Whiteman DAH, Russman BS. Folate deficiency and acute intermittent porphyria in a 12-year-old boy. Neurology 1993; 43:1438-9.

40. Wider de Xifra EA, Batlle AMC, Stella AM, Malamud S. Acute intermittent porphyria - another approach to therapy. Int J Biochem 1980; 12:819-22.

41. Monteiro HP, Abdalla DSP, Faljoni-Alario A, Bechara EJH. Generation of active oxygen species during coupled autoxidation of oxyhemoglobin and delta-aminolaevulinic acid. Biochim Biophys Acta 1986; 881:100-6.

42. Elder GH. Formation of an UPGD inhibitor on oxidation of uroporphyrinogen. In: De Matteis $\mathrm{F}$, Aldridge $\mathrm{W}$, editors. Heme and hemoproteins. Berlin, Heidelberg, New York: Springer-Verlag, 1978:157-200.

43. Smith AG, De Matteis F. Oxidative injury mediated by the hepatic cytochrome P-450 system in conjunction with cellular iron. Effects on the pathway of haem biosynthesis. Xenobiotica 1990; 20:865-77.

44. Hällgren $R$, Svensson $K$, Johansson $E$, Lindh U. Elevated granulocyte manganese in rheumatoid arthritis and other connective tissue diseases. J Rheumatol 1985; 12:876-80.

45. Korc $M$. Manganese as a modulator of signal transduction pathways. Prog Clin Biol Res 1993:235-55.

46. Keen CL, Lönnerdal B, Hurley LS. Metabolism and biochemistry of manganese. In: Frieden E, editor. Biochemistry of he essential ultra-trace elements. New York: Plenum Publishing Company, 1984:89-132.

47. Prohaska JR. Functions of trace elements in brain metabolism. Physiol Rev 1897; 67:858-901.

48. Weisinger RA, Fridovich I. Mitochondrial superoxide dismutase. Site of synthesis and intramitochondrial localization. J Biol Chem 1973; 248:4793-6.

49. Wedler FC, Denman RB. Glutamine synthetase: the major $\mathrm{Mn}(\mathrm{II})$ enzyme in mammalian brain. Current Topics in Cellular Regulation 1984; 24:153-69.

50. Stryer L. Biosynthesis of amino acids and heme. In: Biochemistry. New York: WH Freeman and Company, 1988:575-600

51. Stryer L. Pentose phosphate pathway and gluconeogenesis. In: Biochemistry. New York: WH Freeman and Company, 1988:427-48.

52. Hassan HM. Biosynthesis and regulation of superoxide dismutases. Free Radic Biol Med 1988; 5:377-85.

53. Aust SD, Morehouse LA, Thomas CE. Role of metals in oxygen radical reactions. Free Radic Biol Med 1985; 1:3-25.

54. Hermes-Lima M, Valle GRV, Vercesi AE, Bechara EJH. Damage to rat liver mitochondria promoted by delta-aminolevulinic acid-generated reactive oxygen species: connections with acute intermittent porphyria and lead-poisoning. Biochim Biophys Acta 1991; 1056:57-63.

55. Otezia PI, Bechara EJH. 5-Aminolaevulinic acid induces lipid peroxidation in cardiolipin-rich liposomes. Arch Biochem Biophys 1993; 305:282-7.

56. Halliwell B, Gutteridge JMC. Oxygen radicals and the nervous system. Trends Neurosci 1985; 8:22-6.

57. Shah SV. Role of reactive oxygen metabolites in experimental glomerular disease. Kidney Int 1989; 35:1093-106.

58. Wong GHW, Elwell JM, Oberley LW, Goeddel DV. Manganous superoxide dismutase is essential for cellular resistance to cytotoxicity of tumor necrosis factor. Cell 1989; 58:923-31. 
59. Suzuki K, Tatsumi $H$, Satoh $S$, ${ }^{-}$Senda T, Nakata T, Fujii J, et al. Manganese-superoxide dismutase in endothelial cells: localization and mechanism of induction. Am J Physiol 1993; 265:H1173-8.

60. McCord JM, Fridovich I. Superoxide dismutase: an enzymatic function for erythrocuprein (hemocuprein). J Biol Chem 1969; 244:6049-55.

61. Ingold KU, Webb AC, Witter D. Burton GW, Metcalfe TA, Muller, DPR. Vitamin E remains the major lipid-soluble, chain-breaking antioxidant in human plasma even in individuals suffering severe vitamin E deficiency. Arch Biochem Biophys 1987; 259:224-5.

62. Beyer RE. The participation of coenzyme $Q$ in free radical production and antioxidation. Free Radic Biol Med 1990; $8: 545-65$.

63. Fox JM. Selenium: nutritional implications and prospects for therapeutic medicine. Meth Find Exp Clin Pharmacol 1992; $14: 275-87$.

64. Burton GW, Ingold KU. $\beta$-Carotene: an unusual type of lipid antioxidant. Science 1984; 224:569-73.

65. van Brummelen $R$, Myburgh S, Bissbort SH. The influence of porphyrogenic drugs on the glyoxalase enzymes. Res Commun Chem Pathol Pharmacol 1993; 82:339-49.

66. Mustajoki P, Nordmann Y. Early administration of heme arginate for acute porphytic attacks. Arch Int Med 1993; 153:2004-8.

67. van Brummelen R, Bissbort SH. Chicken eggshell porphyrins and the glyoxalase pathway: its possible physiological role. Comp Biochem Physiol 1993; 104B:657-62.

68. Tschudy DP, Lamon JM. Porphyrin metabolism and the porphyrias. In: Bondy PK, Rosenberg LE, editors. Metabolic control and disease. Philadelphia: Saunders Comp, 1980:939-1007.

69. Cross CE, Halliwell B, Borish ET, Pryor WA, Ames BN, Saul RL, et al. Davis Conference: oxygen radicals and human disease. Ann Intern Med 1987; 107:526-45.

70. Eklöw-Lästbom L, Rossi L, Thor H, Orrenius S. Effects of oxidative stress caused by hyperoxia and diquat: a study in isolated hepatocytes. Free Radic Res Commun 1986; 2:57-68.

71. Snyder SH. Nitric oxide. More jobs for that molecule. Nature 1994; 372:504-5.

72. McCord JM. Mutant mice, $\mathrm{Cu}, \mathrm{Zn}$ superoxide dismutase, and motor neuron degeneration. Science 1994; 266:1586-7.

73. Avraham KB, Sugarman H, Rotshenker S, Groner Y. Down's syndrome: morphological remodelling and increased complexity in the neuromuscular junction of transgenic $\mathrm{CuZn}$ superoxide dismutase mice. J Neurocytol 1991; 20:208-15.

74. Epstein CJ, Avraham KB, Lovetto M, Smith S, Elroy-Stein $\mathrm{O}$, Rotman $\mathrm{G}$, et al. Transgenic mice with increased $\mathrm{Cu} / \mathrm{Zn}$ superoxide dismutase activity: animal model of dosage effects in Down syndrome. Proc Natl Acad Sci USA 1987; 84:8044-8.

75. Yim MB, Chock PB, Stadtman ER. Copper, zinc superoxide dismutase catalyzes hydroxyl radical production from hydrogen peroxide. Proc Natl Acad Sci USA 1990; 87:500610.

76. Courcoux A, Lhermitte J, Boulanger-Pillet M. La paralysie extenso-progressive hématoporphyrique. Press Med 1929; 2:1609-13.

77. Thorner PS, Bilbao JM, Sima AAF, Briggs S. Porphyric neuropathy: an ultrastructural and quantitative nerve study. Can J Neurol Sci 1981; 8:281-7.

78. Kobzik L, Reid MB, Bredt DS, Stamler JS. Nitric oxide in skeletal muscle. Nature $1994 ; 372: 546-8$.

79. Lithner F, Wetterberg L. Hepatocellular carcinoma in patients with acute intermittent porphyria. Acta Med Scand 1984; 215:271-4

80. Kauppinen R, Mustajoki P. Acute hepatic porphyria and hepatocellular carcinoma. Br J Cancer 1988; 57:117-20.
81. Cadet J, Teoule R. Comparative study of oxidation of nucleic acid components by hydroxyl radicals, singlet oxygen and superoxide anion radicals. Photochem Photobiol 1978; 28:661-8.

82. Sun Y. Free radicals, antioxidant enzymes and carcinogenesis. Free Radic Biol Med 1990; 8:583-99.

83. Andersson $C$, Lithner F. Hypertension and renal disease in patients with acute intermittent porphyria. J Int Med 1994; 236:169-75.

84. Greene EL, Paller MS. Calcium and free radicals in hypoxia/ reoxygenation injury of renal epithelial cells. Am J Physiol 1994; 266:F13-F20.

85. Mattson MP, Rydel RE, Lieberburg I, Smith-Swintosky VL. Altered calcium signaling and neuronal injury: stroke and Alzheimer's disease as examples. Ann NY Acad Sci 1993; 679:1-21.

86. McKinnel CE, Ades IZ. Production of $\delta$-aminolevulinate: subcellular localization and purification of murine hepatic Lalanine : 4,5 dioxovaleric acid aminotransferase. Int $\mathrm{J}$ Biochem 1990; 22:347-57.

87. Chabra R, Singh NK, Datta K. Induction of L-alanine : 4,5 dioxovalerate transaminase by phenylhydrazine is associated with depletion of heme level. Biochem Biophys Res Commun 1986; 138:742-50.

88. Fridovich I. Superoxide radical: an endogenous toxicant. Annu Rev Pharmacol Toxicol 1983; 23:239-257.

89. Pryor WA, Prier DG, Church DF. Electron-spin resonance study of mainstream and sidestream cigarette smoke: nature of the free radicals in gas-phase smoke and in cigarette tar. Environ Health Perspect 1983; 47:345-55.

90. Yoshioka T, Homma T, Meyrick B, Takeda M, MooreJarrett $\mathrm{T}$, Kon V, et al. Oxidants induce transcriptional activation of manganese superoxide dismutase in glomerular cells. Kidney Int 1994; 46:405-13.

91. Beatrice MC, Stiers DL, Pfeiffer DR. Increased permeability of mitochondria during $\mathrm{Ca}^{2+}$ release induced by t-butyl hydroxiperoxide or oxalacetate. The effect of ruthenium red. $J$ Biol Chem 1982; 257:7161-71.

92. Lieber CS. Biochemical and molecular basis of alcohol-induced injury to liver and other tissues. N Engl J Med 1988; 319:1639-50.

93. Warso MA, Lands WEM. Presence of lipid hydroperoxide in human plasma. J Clin Invest 1985; 75:667-71.

94. Halliwell B, Gutteridge JMC. Oxygen free radicals and iron in relation to biology and medicine: some problems and concepts. Arch Biochem Biophys 1986; 246:501-14.

95. Arduini A. Carnitine and its acyl esters as secondary antioxidants? Am Heart J 1992; 123:1726-7.

96. Frey B, Kim MC, Ames BM. Ubiquinol 10 is an active lipid soluble antioxidant at physiological concentrations. Proc Natl Acad Sci USA 1992; 87:4879-83.

97. Granick $S$. The induction in vitro of the synthesis of $\delta$-aminolevulinic acid synthetase in chemical porphyria: a response to certain drugs, sex hormones and foreign chemicals. J Biol Chem 1966; 241:1359-75.

98. Gibbons SJ, Brorson JR, Bleakman D, Chard PS, Miller RJ. Calcium influx and neurodegeneration. Ann NY Acad Sci 1993; 579:22-33.

99. Cerutti PA. Prooxidant states and tumor promotion. Science $1985 ; 227: 375-81$.

100. Frenkel K. Carcinogen-mediated oxidant formation and oxidative DNA damage. Pharmacol Ther 1992; 53:127-66.

Associate Professor Stig Thunell
Porphyrias Service Sweden
Karolinska Institute
St. Göran's Hospital
S-11281 Stockholm
Sweden

Associate Professor Stig Thunell

Karolinska Institute

S-11281 Stockholm

Sweden 